\title{
BIOCOMPOSITES BASED ON POLY(LACTIC ACID) AND KENAF FIBERS: EFFECT OF MICROFIBRILLATED CELLULOSE
}

\author{
Gordana Bogoeva-Gaceva ${ }^{1}$, Dimko Dimeski², Vineta Srebrenkoska² \\ ${ }^{1}$ Faculty of Technology and Metallurgy, Ss. Cyril and Methodius University, \\ Skopje, Republic of Macedonia \\ ${ }^{2}$ Faculty of Technology, Goce Delčev University, Štip, \\ Republic of Macedonia \\ gordana@tmf.ukim.edu.mk
}

\begin{abstract}
In this work, the influence of microfibrillated cellulose (MFC) on the basic mechanical properties of PLA/kenaf fiber biocomposites has been studied. The addition of 5-15\% microfibrillated cellulose to a biocomposite premix has resulted in an increased glass transition temperature of the final product, produced by compression molding of previously melt-mixed composite components. The presence of MFC has influenced the interface-sensitive properties of the PLA/kenaf composite: at an optimal loading of $10 \%$, the interfacial energy release rate was increased by about $20 \%$. Moreover, flexural strength and modulus of the composites were also improved (from $34.8 \mathrm{MPa}$ to $57.1 \mathrm{MPa}$ and from $4.9 \mathrm{GPa}$ to $5.8 \mathrm{GPa}$, respectively).
\end{abstract}

Keywords: biocomposites; poly(lactic acid); kenaf fibers; microfibrillated cellulose

\section{БИОКОМПОЗИТИ НА БАЗА НА ПОЛИМЛЕЧНА КИСЕЛИНА И КЕНАФ-ВЛАКНА: ВЛИЈАНИЕ НА МИКРОФИБРИЛАРНАТА ЦЕЛУЛОЗА}

\begin{abstract}
Испитувано е влијанието на микрофибриларната целулоза (МФЦ) врз основните механички својства на биокомпозитите на база на полимлечна киселина со кенаф-влакна. Додатокот на 5-15 \% МФЦ во биокомпозитниот премикс предизвикува зголемување на температурата на стаклосување на продуктот, добиен со пресување на претходно растопените компоненти. Присуството на МФЦ во композитот влијае врз својствата чувствителни на состојбата во граничната површина полимер/влакно: при оптимално количество од 10 \% меѓуфазната енергија се зголемува за околу 20 \%. Покрај тоа, јачината и модулот на свиткување на композитот се зголемени (од 34,8 MPa до 57,1 MPa и од 4.9 GPa на 5,8 GPa, соодветно).
\end{abstract}

Клучни зборови: кенаф-влакна; композити; полимлечна киселина; микрофибриларна целулоза

\section{INTRODUCTION}

Natural fibers-reinforced composites have been used in countless consumer products, including cars, boats, skis, agricultural machinery, etc., during the last decades [1-3]. Among them, biocomposites represent a relatively new class of materials, in which natural fibers are combined with a biodegradable polymer matrix. Special attention as a matrix mate- rial has been given to poly(lactic acid) (PLA), mainly due to its easy processability, similar to polyolefins or other thermoplastics [4-6]. Kenaf fiber-reinforced PLA biocomposites are extensively studied, since they exhibit higher strength values in terms of tensile and flexural properties as compared to other natural fibers used to reinforce PLA [5, 7-10]. Their mechanical properties are comparable to those of E-glass fibers (Table 1) [11]. 
T a b l e 1

Selected properties of some natural fibers in comparison with glass and carbon fibers

\begin{tabular}{lccccc}
\hline \hline Fiber & $\begin{array}{c}\text { Density } \\
\left(\mathrm{gcm}^{-3}\right)\end{array}$ & $\begin{array}{c}\text { Tensile } \\
\text { strength } \\
(\mathrm{MPa})\end{array}$ & $\begin{array}{c}\text { Specific tensile } \\
\text { strength } \\
(\mathrm{MPa})\end{array}$ & $\begin{array}{c}\text { Elastic } \\
\text { modulus } \\
(\mathrm{GPa})\end{array}$ & $\begin{array}{c}\text { Specific elastic } \\
\text { modulus } \\
(\mathrm{GPa})\end{array}$ \\
\hline Cotton & $1.5-1.6$ & 400 & $250-267$ & $5.5-12.6$ & $3.5-8.1$ \\
Sisal & 1.5 & $511-635$ & $341-423$ & $9.4-22$ & $6.3-14.7$ \\
Kenaf & $\mathbf{1 . 4 5}$ & $\mathbf{9 3 0}$ & $\mathbf{6 4 1}$ & $\mathbf{5 3}$ & $\mathbf{3 6 . 5}$ \\
E-glass & 2.5 & $2000-3500$ & $800-1400$ & 70 & 28 \\
Carbon & 1.4 & 4000 & 2857 & $230-240$ & $164-171$ \\
\hline \hline
\end{tabular}

In our previous work [12], we investigated the characteristics of PLA/kenaf fiber composites processed by compression and injection molding, and the obtained results have shown that the overall mechanical properties are comparable to those of conventional formaldehyde wood mediumdensity fiberboards used as construction elements for indoor applications.

The aim of this work was to study the possibility of improving the interface-sensitive properties of PLA/kenaf fiber biocomposites by the addition of nano-sized cellulose fibrils modified with a nucleating agent in order to simultaneously increase the rate of polymer crystallization and thus reduce the time needed for the completion of the processing cycle.

\section{EXPERIMENTAL}

Composites of PLA (Biomer, Germany), retted kenaf fibers (Bast Fiber LLC), and MFC (Pulp Daicel) were prepared by melt mixing the components in a Rheocord apparatus, then consequent compression molding at $180{ }^{\circ} \mathrm{C}$ for 3 min with a pressure of $50 \mathrm{MPa}$. The amount of MFC in the mixture varied from 5-15\%, while the PLA content was kept constant at $50 \%$. Prior to the use in kenaf/PLA composites, MFC was modified with a nucleating agent (talc) [13] in order to increase the rate of polymer crystallization. Additional treatment of composite samples at $100{ }^{\circ} \mathrm{C}$ was performed as a means to increase the crystallinity of the matrix polymer and thus improve the mechanical properties of the composites. These aforementioned properties were determined by a three-point bending test in accordance with ASTM D790. The obtained results represent a mean value of five tested samples. DSC analysis was performed on the PerkinElmer DSC 7 in nitrogen atmosphere. The system was calibrated using elemental indium. The composite samples were heated from $10{ }^{\circ} \mathrm{C}$ to $200{ }^{\circ} \mathrm{C}$ with a heating rate of $10 \mathrm{~K} \mathrm{~min}^{-1}$.

\section{RESULTS AND DISCUSSION}

Among the biodegradable polymers from renewable sources, poly(lactic acid) (PLA) has been recently most widely investigated as a potential matrix for green biocomposites. PLA can be processed in the same way as polyolefins and other thermoplastics, and this advantage is especially important in the processing of biocomposites since it allows use of the same technological equipment as those used for conventional fiberreinforced composite materials. Kenaf fibers, on the other hand, are known as a cellulosic source, with ecological and economical advantages [14]. Kenaf exhibits low density, nonabrasiveness during processing, high specific mechanical properties, and biodegradability [7] and is currently used in paper and pulp industries (an alternative to wood), in the automotive industry and in textiles, as well as for the production of fiberboards $[7,9,10]$. 
Our previous results on kenaf fiber/PLA composites have shown that their mechanical properties are comparable to those of conventional formaldehyde wood medium-density fiberboards used as construction elements for indoor applications [12]. Moreover, it was confirmed that both conventional injection and compression molding techniques could be successfully applied for their production. To improve the compatibility and adhesion between the fibers and the matrix, maleic anhydride-grafted poly(lactic acid) was used as a coupling agent. However, the grafting procedure, although widely accepted as a promising compatibilization strategy [15], always leads to partial matrix degradation, induced by macromolecular scission, thus reducing the PLA molecular weight. This was observed even when the maleic anhydride-grafting degree was as low as $1 \%$ wt. Therefore in this work, we applied another approach to solve the problem of fiber/matrix adhesion. Namely, MFC was additionally treated with a nucleating agent prior to its use in the polymer/fibers premix, and PLA was used without further chemical modification.

A mechanical analysis of neat PLA and PLA/kenaf composites with and without MFC has shown that the addition of MFC has a positive effect on both flexural strength and modulus. The main mechanical properties are reported in Table 2.

\section{Table 2}

\section{Influence of microfibrillated cellulose (MFC) on the flexural properties and fracture toughness of kenaf/PLA composites}

\begin{tabular}{cccc}
\hline \hline $\begin{array}{c}\text { MFC } \\
(\% w t .)\end{array}$ & $\begin{array}{c}\text { Flexural strength } \\
(\mathrm{MPa})\end{array}$ & $\begin{array}{c}\text { Flexural modulus } \\
(\mathrm{GPa})\end{array}$ & $\begin{array}{c}\text { Fracture toughness } \\
\left(\mathrm{kJm}^{-2}\right)\end{array}$ \\
\hline 0 & $34.8 \pm 0.2$ & $3.9 \pm 0.06$ & $2.9 \pm 0.01$ \\
5 & $42.3 \pm 0.7$ & $4.9 \pm 0.06$ & $3.1 \pm 0.02$ \\
10 & $57.1 \pm 0.9$ & $5.8 \pm 0.08$ & $3.9 \pm 0.03$ \\
12.5 & $47.8 \pm 1.2$ & $5.9 \pm 0.09$ & $2.8 \pm 0.10$ \\
15 & $50.0 \pm 1.9$ & $4.6 \pm 0.12$ & $2.7 \pm 0.13$ \\
\hline \hline
\end{tabular}

A significant improvement of up to $60 \%$ in the strength was recorded for MFC loading of 10 $\%$ wt. The improvement of the modulus, in addition to strength increase, is obviously a result of better interfacial adhesion strength achieved by kenaf/PLA/MFC composites. At higher MFC loadings, the decrease in mechanical properties is probably due to the reduced overall fiber-reinforcing component (reduced kenaf fiber/MFC ratio, with constant PLA content of $50 \%$ ). It has been already shown that the presence of kenaf fibers improves the toughness of neat PLA, since the fibers represent a critical area in which the applied load is concentrated $[6,15]$. However, the magnitude of this effect is a function of the fiber/ filler interfacial adhesion, for which the presence of MFC's large surface area represents a favorable condition, as can be seen in the results from the fracture toughness analyses conducted.

In several recently published papers, the possibility of reinforcing PLA matrix with MFC has been studied, with special attention focused on the influence of MFC on the crystallization behavior onto a neat amorphous polymer [1618]. The authors have shown that the appearance of a crystalline structure induced by the presence of cellulose fibrils has affected both static and dynamic mechanical behaviors of PLA.

The presence of MFC along with kenaf fibers has affected the glass transition temperature $\left(T_{g}\right)$ of the matrix, and while the slight increase was recorded for kenaf/PLA composites (see Figure 1), significantly reduced chain mobility of PLA matrix is additionally provoked by MFC. The results of DSC analyses are summarized in Table 3. 


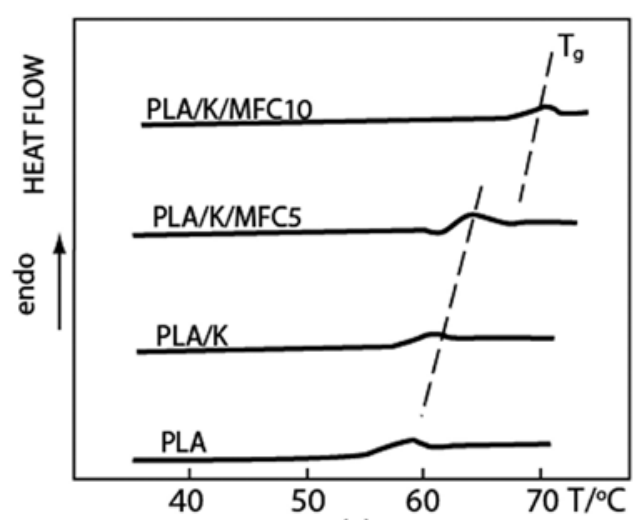

(a)

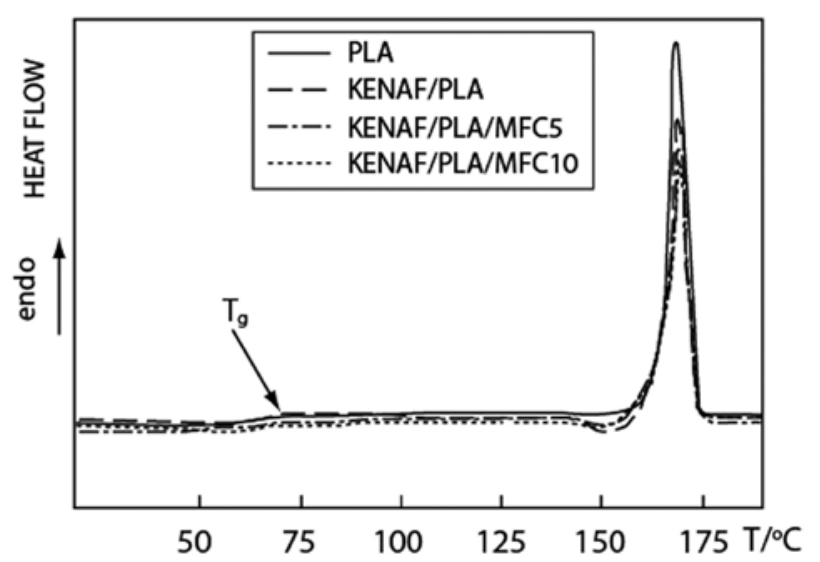

(b)

Fig. 1. DSC heating curves of PLA and PLA/kenaf fiber composites containing 5 and $10 \%$ wt. MFC: glass transition temperature region (a); first heating run from $10{ }^{\circ} \mathrm{C}$ to $200{ }^{\circ} \mathrm{C}$ (b)

$\mathrm{T}$ a b 1 e 3

Glass transition temperature $\left(T_{g}\right)$ of kenaf fiber/PLA composites containing an optimal amount of microfibrillated cellulose (MFC)

\begin{tabular}{lc}
\hline \hline Sample & $T_{g} /{ }^{\circ} \mathrm{C}$ \\
\hline PLA & 57.0 \\
Kenaf/PLA & 61.2 \\
Kenaf/PLA/MFC (5 \%wt.) & 64.6 \\
Kenaf/PLA/MFC (10\%wt.) & 68.9 \\
\hline \hline
\end{tabular}

Although PLA is a crystalline polymer, its crystallization rate is low, and it exhibits features practically similar to those of noncrystalline resins [17]. On the other side, accelerated crystallization is favorable for PLA-based composites in terms of processing conditions and mechanical performance. While the compression molding time of PLA/kenaf composites (determined from our preliminary testing) was $5 \mathrm{~min}$, the ejection time for PLA/kenaf/MFC composites at the same molding temperature and pressure was reduced to $3 \mathrm{~min}$, which certainly represents an important technological benefit.

An attempt was made to further increase the mechanical properties of the composite with optimal loading of MFC (10\%wt.) by annealing the sample at $100{ }^{\circ} \mathrm{C}$ for $30 \mathrm{~min}$. As shown by DSC, the overall crystallinity was increased by about 5-7 \% after the thermal treatment, and the value of $T_{g}$ reached $70{ }^{\circ} \mathrm{C}$. The increase in $T_{g}$ might be the result of transcrystallization phenomena taking place on the surface of MFC fibrils, pretreated with a nucleating agent, as well as of a healing effect, but further investigation is needed to confirm this assumption. However, although the modulus was slightly increased (by $5 \%$ as compared to the untreated composite sample), fracture toughness after annealing was reduced to $3.6 \mathrm{kJm}^{-2}$.

\section{CONCLUSION}

Hybrid PLA-based biocomposites reinforced with kenaf fibers and containing microfibrillated cellulose were prepared by compression molding, and the influence of MFC on interfacesensitive properties was characterized by mechanical analyses. The presence of MFC at an optimal loading of $10 \%$ wt. induces significant improvement of flexural properties and toughness in comparison with PLA/kenaf composites. The interfacial energy release rate of this new type of biocomposite was increased by about $20 \%$.

\section{REFERENCES}

[1] J. Holbery, J. Houston, Natural-fiber-reinforced polymer composites in automotive applications, JOM, 11, 80-86 (2006).

[2] K. Bledzki, O. Faruk, V. E. Sperber, Cars from biofibers, Macromolecular Materials Engineering, 291, 449-457 (2006). 
[3] P. Wambua, J. Ivens, I. Verpoest, Natural fibers: can they replace glass in fiber reinforced plastics? Composite Science and Technology, 63, 12591264 (2003).

[4] K. Oksman, M. Skrifvars and J. F. Selin, Natural fibers as reinforcement in PLA composites, Composite Science and Technology, 63, 1317-1324 (2003).

[5] T. Nishino, K. Hirao, M. Kotera, K. Nakamae and H. Inagaki, Kenaf reinforced biodegradable composites, Composite Science and Technology, 63, 1281-1286 (2003).

[6] H. M. Akil, M. F. Omar, A. A. M. Mazuki, S. Safiee, Z. A. M. Ishak and A. Abu Bakar, Kenaf fiber reinforced composites: A review, Materials and Design, 32, 4107-4121 (2011).

[7] I. S. Aji, S. M. Sapuan, E. S. Zainudin and K. Abdan, Kenaf fibers as reinforcement for polymer composites: A review, International Journal of Mechanics and Materials Engineering, 4, 239248 (2009).

[8] C. W. Chin and B. F. Yousif, Potential of kenaf fibers as reinforcement for tribological applications, Wear, 267, 1550-1557 (2009).

[9] M. Zampaconi, F. Pourboghart, S. A. Yankovich, B. N. Rodgers, J. Moore, L. T. Drzal, A. K. Mohanty, M. Misra, Kenaf natural fiber reinforced polypropylene. Composites. A discussion on manufacturing problems and solutions, Composites: Part A, 38, 1569-1580 (2007).

[10] S. Shibata, Y. Cao, I. Fukumoto, Light weight laminate composites made from kenaf and PP fibers, Polymer Testing, 25, 142-148 (2006).

[11] M. P. Westman, L. S. Fifield, K. L. Simmons, S. G. Laddha and T. A. Kafentzis, Natural fiber com- posites: A review, US Dept. of Energy, DE-reportAC05-76RL01830 (2010).

[12] V. Srebrenkoska, G. Bogoeva-Gaceva and D. Dimeski, Preparation and recycling of polymer eco-composites. I. Comparison of the conventional molding techniques for preparation of polymer eco-composites, Macedonian Journal of Chemistry and Chemical Engineering, 28, 99-109 (2009).

[13] G. Bogoeva-Gaceva, D. Dimeski and V. Srebrenkoska, Poly(lactic acid)/kenaf fiber composites: effect of micro-fibrillated cellulose on interfacesensitive properties, XXII Congress of SHTM, Ohrid, 5-9 Sept. 2012.

[14] A. Bismarck, S. Mishra, T. Lampke, Plant fibers as reinforcement for green composites. A. K. Mohanty, M. Misra, L. T. Drzal, Editors. Natural Fibers, Biopolymers and Biocomposites. Boca Raton (FL), CRC Press, 2005.

[15] M. Avella, G. Bogoeva-Gaceva, A. Buzarovska, M. E. Errico, G. Gentile and A. Grozdanov, Poly(lactic acid)-based biocomposites reinforced with kenaf fibers, Journal of Applied Polymer Science, 108, 3542-3551 (2008).

[16] L. Suryanegara, A. N. Nakagaito, H. Yano, The effect of crystallization of PLA on the thermal and mechanical properties of microfibrillated cellulose-reinforced PLA composites, Composite Science and Technology, 69, 1187-1192 (2009).

[17] A. Iwatake, M. Nogi, H. Yano, Cellulose nanofiber reinforced polylactic acid, Composite Science and Technology, 68, 2103-2116 (2008).

[18] L. Suryanegara, A. N. Nakagaito, H. Yano, Thermo-mechanical properties of microfibrillated cellulose-reinforced partially crystallized PLA composites, Cellulose, 17, 771-778 (2010). 
